\title{
Effect of Spraying With Sorbitol and Boron on Growth Characteristics and Oil Percentage in Rapeseed Brassica napus $L$.
}

\author{
Tahseen Ali Ibrahim AL-Abtan ${ }^{1, a)}$, Wisam Malik Dawood ${ }^{1, b)}$ and Ayad Assi Obaid ${ }^{2, c)}$ \\ ${ }^{1}$ College of Education For Pure Sciences, University of Diyala, Iraq. \\ ${ }^{2}$ College of Agriculture, University of Diyala, Iraq. \\ ${ }^{a)}$ Corresponding Author: tahseenalabtan@gmail.com \\ ${ }^{b)}$ WisamDawood@gmail.com \\ ${ }^{c)}$ Ayadassi73@gmail.com
}

Received : 22/8/2021

Acceptance : 8/9/2021

Available online: $31 / 12 / 2021$

\begin{abstract}
The experiment was carried out in a private agricultural field in Baladrooz district, Diyala Governorate, Iraq in the autumn season 2019-2020 to study the effect of spraying with sorbitol and boron on the vegetative growth characteristics and oil percentage of rapeseed. Spraying of boron 50 and $100 \mathrm{mg}$ gave the highest mean in root length 28.59 and $27.83 \mathrm{~cm}$, number of main roots 32.19 and 32.61, number of pods 739.8 and 746.8, and oil percentage 45.08 and $47.43 \%$ compared to boron $0 \mathrm{mg}$ (untreated plants) which reached $26.36 \mathrm{~cm}, 28.92,616.5$ and $43.24 \%$ respectively, while spraying of sorbitol 30 $\mathrm{g}$ recorded the highest mean in leaf area $298.14 \mathrm{~cm}$, fresh weight of leaves $13.44 \mathrm{~g}$, dry weight of leaves $1.244 \mathrm{~g}$, root length $29.43 \mathrm{~cm}$, main roots number 34.21 , number of pods 746.9 and oil percentage $47.78 \%$ as compared with sorbitol $0 \mathrm{~g}$ (untreated plants) which reached $248.50 \mathrm{~cm}, 10.81 \mathrm{~g}, 0.962 \mathrm{~g}, 25.54 \mathrm{~cm}, 25.49,602.5$ and $41.36 \%$ respectively. The interaction of spraying between sorbitol and boron on rapeseed plants resulted in a significant increase in all studied traits, where treatment of boron $100 \mathrm{mg}$ with sorbitol $30 \mathrm{~g}$ led to a significant increase in leaf area, fresh weight of leaves, dry weight of leaves and root length, which reached $338.33 \mathrm{~cm}, 14.99 \mathrm{~g}, 1.323 \mathrm{~g}$ and $30.16 \mathrm{~cm}$ respectively, whereas the treatment of boron $100 \mathrm{mg}$ with sorbitol $20 \mathrm{~g}$ recorded the highest increase in the number of roots, number of pods and percentage of oil, as it gave $36.50,869.2$ and $49.67 \%$ respectively.
\end{abstract}

Keywords. Rapeseed, Sorbitol, Boron.

\section{I.INTRODUCTION}

The rapeseed plant belongs to Cruciferae family that include black mustard, turnip, and watercress, Brassica napus L. is one of the primary sources of oil in the form of Triacylglycerols (TAGs), the plant grows widely in China, Canada, Australia and South America [1]. The rapeseed oil is not used in human nutrition, but its usefulness has become increasing as a source for the production of biofuels, inks, paints and lubricants [2,3]. The rapeseed crop is one of the most important sources of vegetable oils in the world, and the percentage of oil in seed ranges between $37-45 \%$ [4]. Foliar fertilization with boron and other elements is the best solution to treat the deficiency in the plant, as scientific experiments have proven positivity of foliar fertilization of boron in filling the deficiency of this element,most soils have a relatively low content of boron, where the dissolved and ready boron for the plant constitutes only $10 \%$ of the total boron in the soil, and this deficiency is determined by several factors such as type and $\mathrm{pH}$ of soil, environmental conditions, drought, high rainfall [5]. Alcoholic sugars are carbohydrates, they important products for the photosynthesis process, they move freely and easily within the plant and they called alcohols because of their chemical structure, alcohols are formed when the aldehyde group $(\mathrm{CHO})$ is reduced to $\mathrm{OHCH}_{2}$, and it is known that mannitol and sorbitol facilitate the transport of boron and microelements inside the phloem tubes in a complex form (di-sorbitol borate ester) [6]. The study aimed to evaluate the effect of spraying with sorbitol and boron on growth characteristics in Rapeseed Brassica napus L.

\section{II.MATERIAL AND METHODS}

Preparing the field for cultivation: The designated field for cultivation was prepared, starting with plowing followed by leveling, The field experiment was conducted in the private agricultural field in the autumn season 2019-2020 at Baladrooz district, Diyala Governorate, Iraq. An experiment was arranged as a factorial experiment based on a randomized complete block design with three replications, first factor was four levels of spraying with sorbitol at 
concentrations $\left(0,10,20\right.$ and 30 g. $\left.1^{-1}\right)$, the second factor was three levels of spraying with boron in the form of boric acid $(10.81 \% \mathrm{~B})$ at concentrations $\left(0,50\right.$ and $\left.100 \mathrm{mg} . \mathrm{l}^{-1}\right)$.Cultivation was carried out with three sectors included 12 treatments, distributed randomly inside the each sector. The cultivation was manually by placing the seeds inside the holes and at a depth 1-2 cm on 27/10/2019 by using the seeds of the Pactol variety from the General Company for Agricultural Supplies of the Ministry of Agriculture. The thinning process was carried out after the emergence of seedlings with two leaves, the distance between plants was $4 \mathrm{~cm}$ and length of the line was $14 \mathrm{~m}$, while the distance between the lines $1 \mathrm{~m}$ and between the experimental units $30 \mathrm{~cm}$.Urea fertilizer $\mathrm{N} 46 \%$ was used as a source of nitrogen, which was added at one time after 20 days of germination, the neutral ultrasol fertilizer (NPK + minor elements) was added after 35 days of germination and high phosphate fertilizer after 40 days of germination. The spraying of plants with sorbitol and boron was carried out three times after 45 days of germination with 21 days between the spraying and another, the first spraying was on 19/12/2019 and the last spraying was on 7/2/2020, the spraying was started with sorbitol, then with boron after 72 hours, Sorbitol or boron was well dissolved in distilled water with the addition of 2-3 drops of liquid soap before spraying.

Studied traits: After 10 days from the last spraying, ten plants were randomly selected from each experimental unit for the following traits, leaf area $\left(\mathrm{cm}\right.$. leaf $\left.{ }^{-1}\right)$, fresh and dry weight of leaves $\left(\mathrm{g}\right.$. leaf $\left.{ }^{-1}\right)$, root length $\left(\mathrm{cm}\right.$. plant $\left.{ }^{-1}\right)$, roots number (root. plant ${ }^{-1}$ ), pods number (pod. plant ${ }^{-1}$ ) and oil percentage $\%$, where the oil was extracted from rapeseed using a Soxhlet device, and the estimation was done in the Ministry of Science and Technology laboratories by using a hexane solvent and the percentage of the oil was estimated according to the mentioned method in the American Society of Chemical Analysts [7].

Oil percentage $(\%)=$ weight of the beaker before extraction - weight of the beaker after extraction / weight of the sample x 100.

Statistical analysis: The results were analyzed using the (SAS) program 2003 and the averages were compared with Duncan's polynomial test at a probability level of 0.05 (4).

\section{III.RESULTS}

Data in Table (1) showed that no significant differences between the means of boron levels in leaf area, fresh weight of leaves and dry weight of leaves, while boron 50 and $100 \mathrm{mg}$ was significantly superior in recording the highest mean in root length reached 28.59 and $27.83 \mathrm{~cm}$ respectively as compared with boron $0 \mathrm{mg}$ which reached $26.36 \mathrm{~cm}$, whereas spraying of sorbitol 30,20 and $10 \mathrm{~g}$ was significantly superior in recording the highest mean in leaf area $298.14,285.96$ and $286.54 \mathrm{~cm}$, fresh weight of leaves $13.44,12.89$ and $12.63 \mathrm{~g}$, dry weight of leaves $1.244,1.214$ and $1.170 \mathrm{~g}$ and root length $29.43,28.26$ and $27.14 \mathrm{~cm}$ as compared with sorbitol $0 \mathrm{~g}$ in previous traits which reached $248.50 \mathrm{~cm}, 10.81 \mathrm{~g}, 0.962 \mathrm{~g}$ and $25.54 \mathrm{~cm}$ respectively,the interaction of spraying between sorbitol and boron was significant, where treatment of boron $100 \mathrm{mg}$ with sorbitol $30 \mathrm{~g}$ gave the highest increase in previous traits $338.33 \mathrm{~cm}$, $14.99 \mathrm{~g}, 1.323 \mathrm{~g}$ and $30.16 \mathrm{~cm}$ respectively,spraying of boron levels 100 and $50 \mathrm{mg}$ was significantly superior in recording the highest mean in the number of main roots 32.61 and 32.19, number of pods 746.8 and 739.8 and oil percentage 47.43 and $45.08 \%$ compared to boron $0 \mathrm{mg}$ which reached 28.92, 616.5 and 43.24 respectively, also spraying of sorbitol 30,20 and $10 \mathrm{~g}$ were superior in recording the highest mean in the number of main roots $34.21,33.19$ and 32.06, number of pods 746.9, 800.5 and 654.2 and oil percentage 47.78, 47.29 and $44.58 \%$ compared to sorbitol $0 \mathrm{~g}$ which reached $25.49,602.5$ and $41.36 \%$ respectively, whereas through the interaction of spraying between sorbitol and boron, the treatment of boron $100 \mathrm{mg}$ with sorbitol $20 \mathrm{~g}$ recorded the highest increase in previous traits $36.50,869.2$ and $49.67 \%$ respectively.

\section{IV.DISCUSSION}

Spraying with sorbitol led to an increase in vegetative growth indicators, the reason is attributed to the important role of alcoholic sugars to transport macro and micro nutrients, especially slow-moving elements such as calcium and boron through the phloemto the leaves, roots, stems and branches of plants, which move freely and easily within the plant,transfer of boron and macro and micro nutrients improves physiological and biochemical processes, due to boron and other nutrients are an important factor in the process of photosynthesis and protoplasmic building besides respiration and the synthesis of DNA and RNA for cell division [8,9]. The transfer of macro and micro nutrients leads to an increase in the accumulation of carbohydrates in the leaves, branches and roots, as well as a decrease in the activity of the IAA-oxidase enzyme, thus increasing the auxin content, which leads to the growth activation, and this is reflected positively on the roots growth indicators [10,11]. These results are consistent with [12], when spraying sorbitol on kiwi plants, [13], on the pepper plant, [14] on Strawberry plant and [15] on eggplant.

Spraying boron on the leaves led to an increase in vegetative growth indicators, may be due to the active role of boron in the transfer of nutrients to areas of the active growth, which provided an opportunity for a large increase in 
nutrients to reach to the leaves, as well as the role of boron in providing and increasing the activity of growth hormones that support chlorophyll and increase the greenness of the plant, all of which leads to an increase in the content of chlorophyll in the plant [16]. The reason may be attributed to the role of boron in building a highly efficient root system in absorbing macro and micro nutrients and increasing their concentration within the plant $[17,18]$. Boron has a positive role in activating and increasing the effectiveness of growth hormones, especially auxins and cytokinins [19]. Boron also plays an important role in the formation of proteins in plants through the formation of RNA, the work of membranes, nitrogen metabolism and photosynthesis, increasing the amount of carbohydrates and proteins in the leaves [20]. Boron improves physiological and biochemical processes during the activation of meristematic tissues, increasing the elongation and cell division and increasing the production and effectiveness of growth regulators, which reflected positively on the vegetative growth indicators [21].

\section{V.CONCLUSION}

According to the findings of the study, Spraying of sorbitol and boron by using different levels separately or combined through the interaction led to an increase in vegetative growth characteristics of Rapeseed.

TABLE 1. Effect of spraying with sorbitol and boron on growth characteristics and oil percentage in Rapeseed Brassica napus.

\begin{tabular}{|c|c|c|c|c|c|c|c|c|c|}
\hline \multicolumn{10}{|c|}{ Leaf area $\left(\mathrm{cm}\right.$. leaf $\left.^{-1}\right)$} \\
\hline \multirow{2}{*}{ 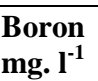 } & \multicolumn{7}{|c|}{ Sorbitol g. $\mathrm{l}^{-1}$} & \multirow{2}{*}{\multicolumn{2}{|c|}{ Mean }} \\
\hline & \multicolumn{2}{|c|}{ 0 } & 10 & \multicolumn{4}{|l|}{20} & & \\
\hline 0 & 241.32 & $\mathrm{c}^{\mathrm{c}}$ & $265.40^{b c}$ & 278.76 & & 294.75 & $a b c$ & 270.06 & A \\
\hline 50 & 249.35 & & $311.28^{\mathrm{ab}}$ & 276.20 & & 261.33 & bc & 274.54 & A \\
\hline 100 & 254.82 & & $282.95^{\mathrm{abc}}$ & 302.92 & & 338.33 & $3^{a}$ & 294.75 & \\
\hline Mean & 248.50 & & $286.54^{\mathrm{A}}$ & 285.96 & & 298.14 & $4^{\mathrm{A}}$ & & \\
\hline \multicolumn{10}{|c|}{ Fresh weight of leaves $\left(\mathrm{g}\right.$. leaf $\left.^{-1}\right)$} \\
\hline 0 & 10.14 & & $11.18^{\mathrm{ab}}$ & 12.85 & & 13.39 & $\mathrm{ab}$ & 11.88 & A \\
\hline 50 & 10.26 & & $13.41^{\text {ab }}$ & 12.58 & & 11.93 & $\mathrm{ab}$ & 12.04 & A \\
\hline 100 & 12.03 & ab & 13.31 ab & 13.25 & & 14.99 & a & 13.40 & A \\
\hline Mean & 10.81 & B & $12.63^{\mathrm{AB}}$ & 12.89 & & 13.44 & A & & \\
\hline \multicolumn{10}{|c|}{ Dry weight of leaves $\left(\mathrm{g}\right.$. leaf $\left.^{-1}\right)$} \\
\hline 0 & 0.844 & & $1.080^{\mathrm{ab}}$ & 1.269 & & 1.238 & & 1.108 & A \\
\hline 50 & 0.995 & & $1.225^{\mathrm{ab}}$ & 1.192 & & 1.169 & & 1.145 & A \\
\hline 100 & $1.013^{\circ}$ & & $1.205^{\mathrm{ab}}$ & 1.179 & & 1.323 & & 1.180 & A \\
\hline Mean & 0.962 & B & $1.170^{\mathrm{A}}$ & 1.214 & & 1.244 & A & & \\
\hline \multicolumn{10}{|c|}{ Root length $\left(\mathrm{cm}\right.$. plant $\left.^{-1}\right)$} \\
\hline 0 & 22.88 & f & $26.25^{\mathrm{de}}$ & $27.23^{c}$ & & 29.07 & $\mathrm{abc}$ & 26.36 & B \\
\hline 50 & $28.37^{\mathrm{a}}$ & & $28.85^{a b c}$ & 29.09 & & 29.05 & & 28.59 & A \\
\hline 100 & 25.36 & & $26.33^{\mathrm{de}}$ & 29.45 & & 30.16 & & 27.83 & A \\
\hline Mean & 25.54 & & $27.14^{\mathrm{C}}$ & 28.26 & & 29.43 & & & \\
\hline \multicolumn{10}{|c|}{ Main roots number (root. plant ${ }^{-1}$ ) } \\
\hline 0 & 23.57 & $\mathrm{e}$ & 28.60 cde & 30.90 & bed & 32.60 & $\mathrm{abc}$ & $28.92^{1}$ & B \\
\hline 50 & 26.93 & de & $33.37^{a b c}$ & 32.17 & $a b c$ & 36.27 & $\mathrm{ab}$ & $32.19^{2}$ & A \\
\hline 100 & 25.97 & de & $34.20 \quad$ ab & 36.50 & a & 33.77 & $\mathrm{abc}$ & 32.61 & A \\
\hline Mean & 25.49 & B & $32.06 \mathrm{~A}$ & 33.19 & A & 34.21 & A & & \\
\hline \multicolumn{10}{|c|}{ Pods number (pod. plant ${ }^{-1}$ ) } \\
\hline 0 & 454.1 & 1 & $557.8 \mathrm{k}$ & 681.6 & $\mathrm{~h}$ & 772.6 & c & $616.5^{1}$ & B \\
\hline 50 & 688.6 & $\mathrm{~g}$ & 564.6 & 850.8 & $\mathrm{~b}$ & 765.1 & d & 739.8 & A \\
\hline 100 & 664.9 & $\mathrm{i}$ & 750.0 & 869.2 & a & 703.1 & $\mathrm{f}$ & 746.8 & A \\
\hline Mean & 602.5 & B & $654.2 \quad$ в & 800.5 & A & 746.9 & A & & \\
\hline \multicolumn{10}{|c|}{ Oil percentage $\%$} \\
\hline 0 & 39.60 & $\mathrm{k}$ & $42.14^{i}$ & 44.40 & $\mathrm{f}$ & 46.80 & e & 43.24 & $\mathrm{C}$ \\
\hline 50 & 41.70 & $\mathrm{j}$ & $44.07 \mathrm{~g}$ & 47.80 & c & 47.37 & d & 45.08 & B \\
\hline 100 & 43.40 & $\mathrm{~h}$ & $47.50^{\mathrm{d}}$ & 49.67 & a & 49.17 & $\mathrm{~b}$ & 47.43 & A \\
\hline Mean & 41.36 & $\mathrm{D}$ & $44.58^{\mathrm{C}}$ & 47.29 & B & 47.78 & A & & \\
\hline
\end{tabular}

\section{REFERENCES}


[1] Abu Dahi, Y M, Al-Younes M A 1988. Plant Nutrition Handbook. Ministry of Higher Education and Scientific Research. The Republic of Iraq.

[2] Al-Hakim M S M 2017. Effect of foliar feeding with manganese and boron on some quantitative and qualitative characteristics of maize plant Zea mays L. under water stress conditions. Karbala University Scientific Journal, Volume Fifteen, Issue One, Scientific: 233-241.

[3] Ali N S, Rahi H S ,Shaker A A 2014. soil fertility. Scientific Books House for Printing, Publishing and Distribution. Baghdad - Iraq.

[4] Al-Rawi K M and Khalaf Allah A A M 2000. Design and analysis of agricultural experiments, Ministry of Higher Education and Scientific Research, University of Mosul, Iraq.

[5] Al-Shammari M F M 2018. The role of spraying boron and sugar alcohols (sorbitol and mannitol) in growth, yield and seeds of pepper plants. PhD thesis, College of Agricultural Engineering Sciences, University of Baghdad.

[6] Annie V 2005. Effect of Boron and Zinc on yield, Uptake and availability of micronutrients on Cauliflower. Madras Agric, J.92 (10-12) : 618- 628 .

[7] AOAC (Association of Official Analytical Chemists) 1995. Official Methods of Analysis, 16 ${ }^{\text {th }}$ Edition. AOAC International, Gaithersburg, MD.

[8] Aydn A and Sevine A 2006. The effect of boron (B) on the growth and nutrient contents of Maize in Zinc (Zn) deficient soils.Research Journal of Agriculture and Biological Sciences, 2 (1) pp 1-4.

[9] Bielski R L2005. Taxonomic patterns in the distribution of polyols within the proteaceae.Aust J Bot (53), 205-217.

[10] Boras M 1998. The importance of rapeseed oil (Colza) and future prospects for its cultivation in the Arab world. Journal of Agriculture and Development in the Arab World, Issue (3), pp. 25-17.

[11] Durrett T P,Benning C, Ohlrogge J 2008. Plant triacylglycerols as feedstocks for the production of biofuels.plant J.54:593607. https://doi.org/10.1111/j.1365-313x.2008.03442.x PMID:184768866.

[12] FoleyJ A, Ramankutty N, Brauman K.A, Cassidy E.S, Gerber J.S, Johnston M 2011.Solution for acultivated.Nature;478:337-342.https://doi.org/10.1038/nature 10452 PMID:21993620.

[13] Hamdi M A. 2016. Germination of kiwi seeds and seedling growth and adaptation in field conditions and tissue culture. Master's Thesis, University of Diyala.

[14] Hu H, Penn S G, LebrillaC B and Brown P H 1997. Isolation and characterization of soluble boron complexes in higher plants. Plant physiol . $113: 649-655$.

[15] Issa D B,AlturkiS M,SajyanT K and SassineY N 2020.Sorbitol and lithovit-guano25 mitigates the adverse effects of salinity on eggplant grown in pot experiment.Agronomy research18(1),113-126.https:doi.org/10.15159/AR.20.075.

[16] KumarA, Sharma A, Upadhyaya K C 2016.Vegetable oil.Nutrition and Industrial perspective.Current Genomics.11:230240.

[17] Mengel K and KirkhyE A 1987. Principles of plant Nutrition.Transalated to Arabic by Saadalaa N.A.Al-Neamymi. Ministry of Higher Education and Scientific Research. University of Mosul.Mosul press.pp.778.

[18] Moeinian M R,Kavveeh Z and JavadH 2011. Effect of boron Foliar Spraying Application on Quality characteristics and Growth Parameters of Wheat Grain under Drought stress. American - Eurasian J. Agric . Environ. Sci . 10 (4): $593-599$.

[19] Mulan H R and Obeid A A 2019. Effect of spraying with sorbitol and boron on the yield and germination of strawberry seeds. FragariaananassaDuch, Ministry of Agriculture, Iraq, College of Agriculture - University of Diyala.

[20] Shorroks V M 1997. The occurrence and correction of boron deficiency. Plant Soil. 193:121-148.

[21] Silke W 2011. Boron foliar fertilization Impacts: on Absorption and Subsequent Translocation of Foliar Applied Boron. Ph.D.Dissertation in Agricultural Sciences. Faculty of Agricultural sciences. University of Hohenheim Germany.pp :93-97. 